Research Paper

\title{
Cysteinyl leukotriene receptor 1 facilitates tumorigenesis in a mouse model of colitis-associated colon cancer
}

\author{
Janina Osman ${ }^{1, *}$, Sayeh Savari ${ }^{1, *}$, Naveen Kumar Chandrashekar ${ }^{1}$, Kishan \\ Bellamkonda ${ }^{1}$, Desiree Douglas ${ }^{1}$, Anita Sjölander ${ }^{1}$ \\ ${ }^{1}$ Division of Cell and Experimental Pathology, Department of Translational Medicine, Lund University, Skåne University Hospital, \\ SE-205 02, Malmö, Sweden \\ *These authors contributed equally to this work \\ Correspondence to: Anita Sjölander, email: Anita.Sjolander@med.lu.se \\ Keywords: CySLT 1 receptor, $L T D_{4}$ signaling, colon cancer, colitis-associated colon cancer (CAC), inflammation \\ Received: December 19, $2016 \quad$ Accepted: March 20, 2017 Published: March 30, 2017 \\ Copyright: Osman et al. This is an open-access article distributed under the terms of the Creative Commons Attribution License (CC-BY), \\ which permits unrestricted use, distribution, and reproduction in any medium, provided the original author and source are credited.
}

ABSTRACT

Cysteinyl leukotriene receptor $1\left(\operatorname{CysLT}_{1} R\right)$ has been shown to be up-regulated in the adenocarcinomas of colorectal cancer patients, which is associated with a poor prognosis. In a spontaneous model of colon cancer, CysLT $R$ disruption was associated with a reduced tumor burden in double-mutant female mice ( ApC $\left.^{\mathrm{Min} /+} / \mathrm{Cys}_{\mathrm{ttr1}} \mathrm{I}^{-/}\right)$ compared to $A \boldsymbol{A c}^{\mathrm{Min} /+}$ littermates. In the current study, we utilized a genetic approach to investigate the effect of CysLT $R$ in the induced azoxymethane/dextran sulfate sodium (AOM/DSS) model of colitis-associated colon cancer. We found that AOM/ DSS female mice with a global disruption of the Cys/tr1 gene (Cys/tr1 ${ }^{-/-}$) had a higher relative body weight, a more normal weight/length colon ratio and smaller-sized colonic polyps compared to AOM/DSS wild-type counterparts. The Cys/tr1 $1^{-/-}$colonic polyps exhibited low-grade dysplasia, while wild-type polyps had an adenoma-like phenotype. The Cys/tr1 ${ }^{-/-}$colonic polyps exhibited significant decreases in nuclear $\beta$-catenin and COX-2 protein expression, while the normal crypts surrounding the polyps exhibited increased Mucin 2 expression. Furthermore, Cys/tr1 ${ }^{-/-}$mice exhibited an overall reduction in inflammation, with a significant decrease in proinflammatory cytokines, polyp 5-LOX expression and infiltration of CD45 leukocytes and F4/80 macrophages. In conclusion, the present genetic approach in an AOM/DSS model further supports an important role for $\operatorname{CysLT}_{1} R$ in colon tumorigenesis.

\section{INTRODUCTION}

Patients suffering from inflammatory bowel disease (IBD) have an approximately 2 - to 5 -fold increased risk of developing colorectal cancer compared to age-matched healthy individuals. IBD involves chronic inflammation of the intestinal tract and includes ulcerative colitis (UC) and Crohn's disease (CD) [1]. The risk factors of developing colorectal cancer in IBD patients include a family history of colorectal cancer, early age of onset of colitis and the concomitant presence of primary sclerosing cholangitis. Other established risk factors are the duration, extent and severity of the inflammation [2]. In accordance with the link between chronic intestinal inflammation and the development of colorectal cancer, studies have shown that the treatment of IBD patients with anti-inflammatory amino salicylates reduces the risk of developing colorectal cancer [3]. Additionally, in the azoxymethane/dextran sodium sulfate model of colitis-associated colorectal cancer (CAC), 5-amino salicylic acid has been shown to reduce the number of dysplastic lesions [4].

Colon cancer development has been shown to be promoted by the irregular metabolism of arachidonic acid, an $\omega-6$ family of polyunsaturated essential fatty acids, which ultimately leads to the generation of the proinflammatory lipid mediators prostaglandins and leukotrienes via cyclooxygenase (COX) isozymes 1 and 2 and 5-lipoxygenase (5-LOX), respectively [5]. The leukotrienes (LTs) are generated by 5-LOX, and $\mathrm{LTC}_{4}$, $\mathrm{LTD}_{4}$ and $\mathrm{LTE}_{4}$ are denoted as cysteinyl leukotrienes (CysLTs) due to their cysteine amino acid residue [6]. The involvement of 5-LOX in the chronic inflammatory condition of IBD is evident from the findings of a 3-7fold increase in 5-LOX expression in the colonic biopsies 
of patients with active IBD compared to controls and elevated urine levels of $\mathrm{LTE}_{4}$ in patients with active $\mathrm{UC}$ and CD [7]. In addition to the increased levels of $\mathrm{PGE}_{2}$ in the inflamed colonic tissues, elevated levels of leukotrienes ( $\mathrm{LTB}_{4}$ and CysLTs) could also be detected in a guinea pig model of IBD [8]. In a chemically induced rat model of IBD, the administration of a dual $\mathrm{LTC}_{4}$ and $\mathrm{LTD}_{4}$ antagonist reduced the colonic damage and inflammation, as evidenced by the reduced levels of $\mathrm{LTC}_{4}$ [9].

CysLTs mediate their effects through G-protein coupled receptors (GPCRs), chiefly CysLT $\mathrm{R}_{1}$ and $\mathrm{CysLT}_{2} \mathrm{R}$ [10]. Increased CysLT $R$ expression has been observed in several human solid tumors, including colorectal cancer [11-16]. We have shown that the up-regulated CysLT $R$ tumor expression in breast and colorectal cancer patients predicts a negative prognosis $[11,16]$, whereas concurrent low $\mathrm{CysLT}_{1} \mathrm{R}$ and high $\mathrm{CysLT}_{2} \mathrm{R}$ expression in colonic tumors convey a favorable prognosis [17]. We have also shown that the $\mathrm{LTD}_{4}$-induced CysLT $\mathrm{R}$ signaling is important in promoting colorectal tumorigenesis by increasing the expression of proteins associated with cell survival (COX-2 and Cyclin D1) and increased proliferation and migration ( $\beta$-catenin) in xenograft colon cancer and colon cancer cell lines [18-20]. In a mouse xenograft study, we demonstrated that the $\mathrm{CysLT}_{1} \mathrm{R}$ antagonist treatment reduces the colon cancer tumor growth by impairing angiogenesis, inducing apoptosis and inhibiting proliferation [21]. In the $\mathrm{Apc}^{\mathrm{Min} /+}$ mouse model, the loss of function of the tumor suppressor gene Adenomatous polyposis coli $(A p c)$ is an early event in tumorigenesis, which is consistent with autosomal dominant inherited colorectal cancer (familial adenomatous polyposis; FAP) and sporadic colorectal cancer [22, 23]. Additionally, in an $\mathrm{Apc}^{\mathrm{Min} /+}$ mouse model of sporadic CRC, female doublemutant $A p C^{\mathrm{Min}+} / C_{\text {Cysltr }} 1^{--}$mice developed fewer intestinal polyps compared to their $A p c^{\mathrm{Min} /+}$ littermates [24]. However, one of the disadvantages of $\mathrm{Apc}^{\mathrm{Min} /+}$ mice is that they are predisposed to multiple neoplasms (Min) that occasionally progress to adenocarcinomas in the small intestine, although very few neoplastic lesions develop in the colon [25].

Therefore, to study the impact of CysLT $\mathrm{R}$ in colitisassociated colorectal cancer, we employed the azoxymethane/ dextran sodium sulfate (AOM/DSS) model in mice with disrupted expression of CysLT $R$. This model is a two-step model where the tumor development in the colon is initiated with the carcinogen azoxymethane and then promoted by the administration of the irritant dextran sodium sulfate [26].

\section{RESULTS}

\section{AOM/DSS treatment induced colitis in Cysltr1 $^{-/-}$ female mice and their wild-type counterpart}

To investigate the role of Cysltr1 in colitisassociated colorectal cancer, wild-type and $\mathrm{CysLT}_{1} \mathrm{R}$ mutant mice $\left(\right.$ Cysltr $\left.^{--/}\right)$were exposed to AOM and DSS as depicted in Figure 1A. The clinical severity of the colitis was determined by measuring the body weight every third day throughout the experiment (Figure 1C) and calculating the colon weight/length ratio for early (colitis, Figure 1B) and late (CAC, Figure 1G) end-points. The AOM/DSS animals, irrespective of their Cysltr 1 genotype, showed a clear drop in relative body weight after the second DSS cycle, with the Cysltr $1^{-/}$mice being less affected by the AOM/DSS treatment. The AOM/DSS Cysltr $1^{-/}$mice euthanized at the early (colitis) and late (CAC) endpoints had a significantly decreased colon weight/length ratio compared to their wild-type counterparts (Figure 1B and $1 \mathrm{G})$. This was mainly due to the more normal-sized colons in Cysltr $\mathrm{I}^{-/}$mice (Figure 1E and 1F). Collectively, these results are indicative of induced colitis in the AOM/DSS-treated animals and correspond well to the clinicopathologic signs of chronic ulcerative colitis in mice, as described by Inoue et al. [27].

\section{Smaller colonic polyps were observed in AOM/ DSS Cysltr1 ${ }^{-/-}$mice}

Mice treated with vehicle control did not display any colonic polyps and no increase in inflammatory infiltrate and edema in the submucosa (Figure 1A). No spontaneous polyps were observed in vehicle control mice (Figure 1E). When comparing the mean numbers of polyps for the AOM/DSS Cysltr $1^{-/-}$mice and their wild-type counterparts $\left(C_{y s l t r 1^{++}}\right)$, no significant difference was observed, although the Cysltr $1^{-/-}$mice clearly exhibited polyps of a smaller size (Figure $1 \mathrm{H})$. The AOM/DSS Cysltr ${ }^{-/-}$mice mainly exhibited colonic polyps of $<1 \mathrm{~mm}$ in diameter with no

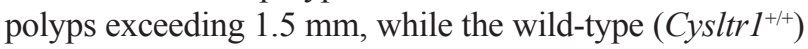
counterparts exhibited all sizes of polyps, including polyps exceeding $1.5 \mathrm{~mm}$ in size (Figure $1 \mathrm{H}$ and $1 \mathrm{I}$ ).

Figure 2A showing vehicle control normal areas stained with hematoxylin and eosin (H\&E) Cysltr ${ }^{-/}$ mice and their wild-type counterparts $\left(\right.$ Cysltr $\left.^{+++}\right)$, The AOM/DSS treatment induced dysplastic lesions/ aberrant crypt foci (ACF) in the mouse colons, and H\&E staining revealed that the wild-type polyps were serrated adenomatous structures, while the Cysltr $1^{-/-}$polyps were low-grade dysplastic in nature (Figure 2B). Shortening of the colon length in DSS mice is one of the biological markers of severity of colonic inflammation [27] and our results clearly show that the Cysltr $1^{-/-}$mice have a less severe colitis with a more normal-like colon length (with reduced colonic inflammation and edema, see Figure 2) and a lower grade of dysplasia compared to the wild-type mice. Figure $2 \mathrm{C}$ shows negative $\mathrm{IgG}$ control stainings.

\section{Decreased expression of nuclear $\beta$-catenin and COX-2 in tumors of AOM/DSS Cysltr $1^{-1-}$ mice}

The nuclear localization of $\beta$-catenin is believed to be required for the CRC progression and is found in late 

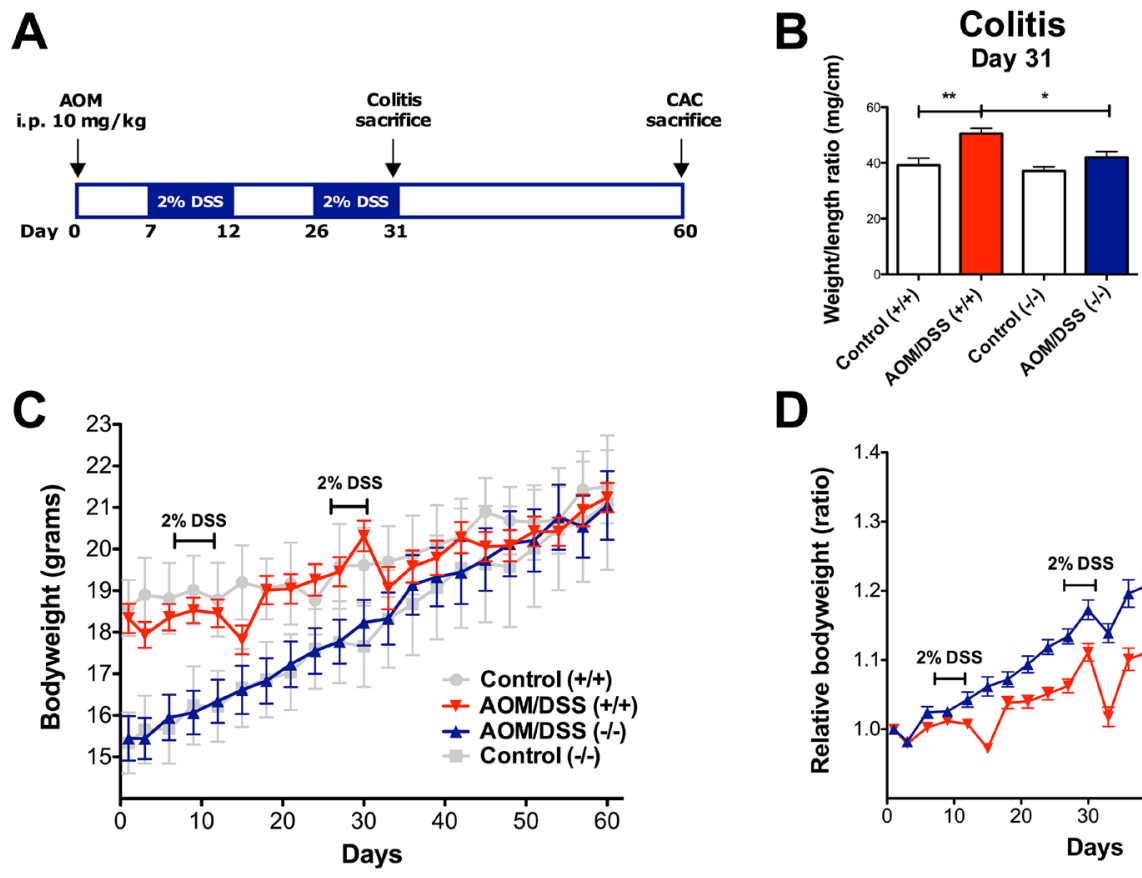

D
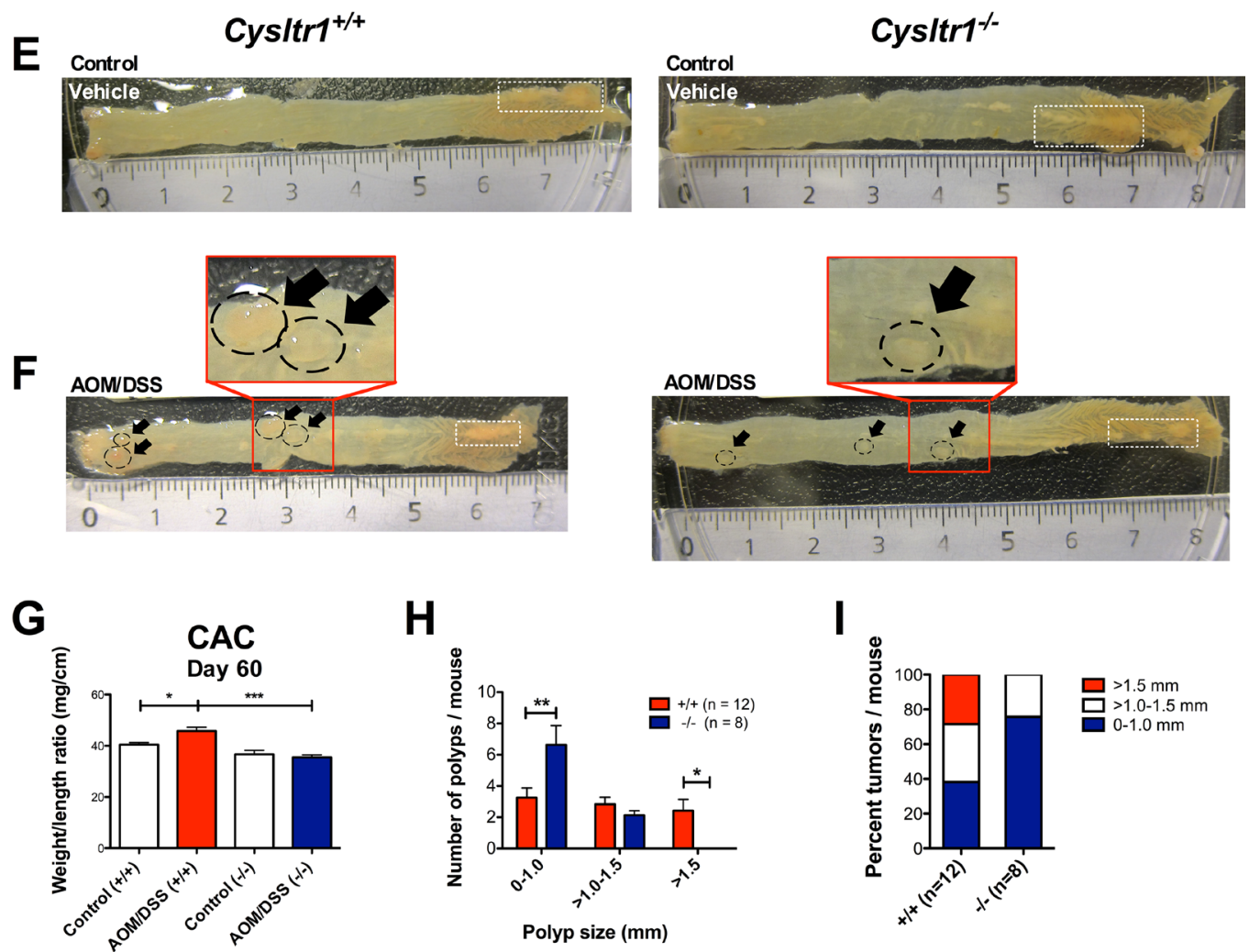

Figure 1: Effect of CysLT $R$ expression on AOM/DSS-induced colitis-associated colon tumorigenesis. (A) Schematic overview of the AOM/DSS-induced colitis-associated colon cancer model. (B) Colon weight/length ratio assessed at colitis end-point (day 31) for untreated vehicle control and AOM/DSS-treated mice ( $n=5-7$ for each genotype). (C) Actual mouse body weight (grams) for AOM/DSS and vehicle control female wild type and Cysltr $1^{--}$mice. (D) Relative body weights of female mice of indicated Cysltr1 genotypes. For wild-type (+/+) females, 12 mice were euthanized at the late CAC end-point (day 60). For Cysltr $1^{-/-}(-/-)$females, eight mice were euthanized at day 60 . Colon weight/length ratio assessed at day 31 for untreated control and AOM/DSS-treated mice $(n=5-7$ for each genotype). Representative images of (E) vehicle control colons from wild type and Cysltr $1^{-1-}$ females at day 60 and (F) AOM/DSStreated colons from wild-type and Cysltr1 $1^{-/}$mice at CAC end-point. (Polyps are indicated by arrows and fat appendages are indicated by white dotted boxes). (G) Colon weight/length ratio assessed at the late end-point (day 60) for vehicle control $(n=7-8)$, AOM/DSS-treated mice ( $n=8$ for wild-type and $n=12$ for Cysltr $1^{-/}$mice). (H) Polyp size and number in the colon were evaluated for AOM/DSS Cysltr $1^{-/-}$ mice and their wild-type counterparts. (I) Percentage of polyps per size group for each genotype. Quantitative data are shown as the mean \pm SEM. $* P<0.05, * * P<0.01, * * * P<0.001$ by unpaired $t$-test and two-way ANOVA for polyp size distribution analysis. 


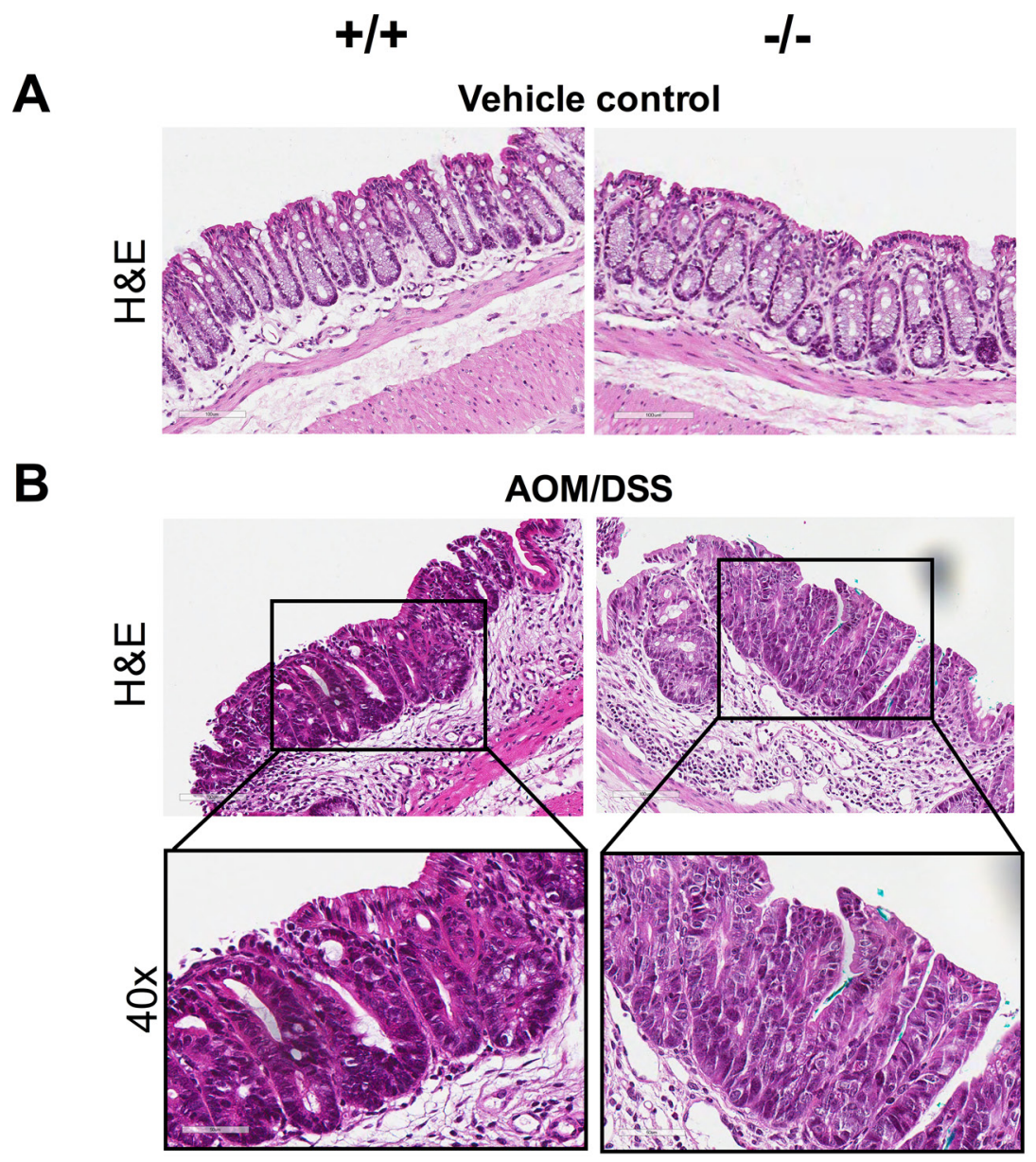

C

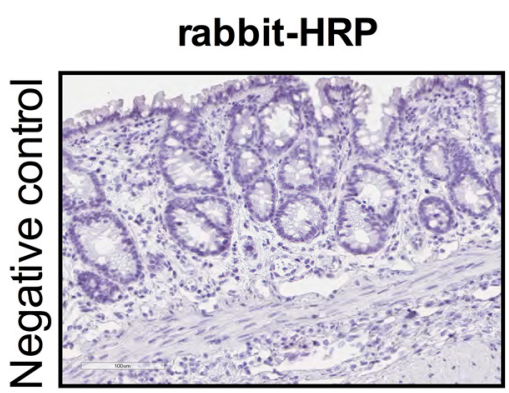

rabbit anti-rat, rabbit-HRP

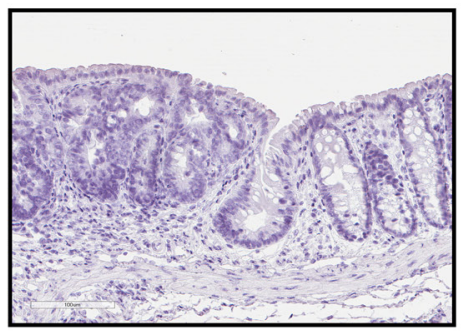

\section{Flex mouse/rabbit-HRP}

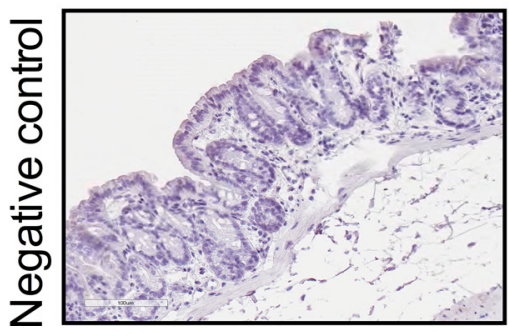

Figure 2: Dysplastic lesions/ACFs developed in AOM/DSS mice independent of Cysltr1 status. The colons of vehicle control and AOM/DSS mice with different Cysltr1 genotype were processed for immunostaining. (A) Representative images $(20 \times$ ) of hematoxylin and eosin staining of vehicle control colons with no observed polyps. (B) Representative images $(20 \times$ and $40 \times)$ of AOM/DSS female mice with different Cysltrl genotypes with dysplastic lesions/ACFs stained for hematoxylin and eosin $(n=3-6$ per genotype). (C) Negative controls (IgG controls) for all the secondary antibodies used, rabbit-horseradish peroxidase (HRP), rabbit anti-rat with rabbit-HRP, and combined Flex mouse/rabbit-HRP. 
adenomas and carcinomas [28]. We, therefore, investigated the effect of the global Cysltr1 gene disruption on tumors by antibody immunostaining for $\beta$-catenin. No difference was observed in $\beta$-catenin localization of non-polyp areas in AOM/DSS mice (Figure 3A). In polyps, a difference in the tumor subcellular localization of the expressed $\beta$-catenin could be observed. The Cysltr $1^{-/-}$mice had increased membranous and decreased nuclear $\beta$-catenin expression compared to the wild-type mice (Figure 3B). However, when analyzing the Cysltr $1^{-/}$colons with identified tumors, the total ctnnbl ( $\beta$-catenin) mRNA expression was not significantly reduced compared to that of the wild-type mice (Figure 3D). Therefore, the smaller polyps observed in the Cysltr $1^{-/}$mice could be due to the decreased nuclear accumulation of $\beta$-catenin.

When $\beta$-catenin translocates to the nucleus, it can act as a transcription factor, and one of its target genes is cyclooxygenase-2 (COX-2) [29]. Therefore, we investigated if there was any change in the COX-2 expression in the tumor epithelium. We stained and assessed the COX-2 expression in the tumors. The colonic tumors of the AOM/DSS Cysltr $1^{-/-}$mice had significantly decreased COX-2 protein expression $(P<0.05)$ compared to the wild-type mice (Figure 3C). The Cysltr $1^{-1}$ colons also displayed a decrease in the ptgs 2 (COX-2) mRNA expression (Figure 3D). No difference was seen in cyclin $D 1$, an additional $\beta$-catenin target gene, but an increase was seen in the enzyme responsible for prostaglandin $\mathrm{E}_{2}$ catabolism, 15-hydroxyprostaglandin dehydrogenase (15-PGDH) (Figure 3D) [30].

\section{Increased expression of Muc-2 in crypts of Cysltr $^{-/-}$mice}

Mucin 2 (Muc-2) is the most prominent secreted gastrointestinal mucin and a differentiation marker for goblet cells. The reduced number of Muc-2 producing goblet cells is characteristic of aberrant crypt foci (ACF), pre-neoplastic lesions that occur in both humans and rodents [31-33]. We observed an increased expression of Muc-2 $(P<0.05)$ in the crypts surrounding the polyps in Cysltr $1^{-/-}$mice compared to those of their wild-type counterparts (Figure 4A).

\section{Reduced expression of 5-LOX and decreased immune cell infiltration in tumors of AOM/DSS

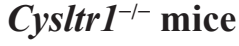

To investigate the effect of $\operatorname{CysLT}_{1} \mathrm{R}$ on the inflammatory status in AOM/DSS mice, we performed immunostaining and assessed the expression of the enzyme responsible for CysLT production, 5-LOX, in tumors. The colonic tumors of the AOM/DSS Cysltr1 ${ }^{-1-}$ mice had significantly decreased 5-LOX protein expression $(P<0.05)$ compared to their wild-type counterparts (Figure 4B). However, the Cysltr ${ }^{-/}$colons with tumors did not display a significant decrease in the alox5 (5-LOX) mRNA expression compared to those of the wild-type mice (Figure 5).

Immune cells are known to infiltrate tumors [34], and the $\mathrm{CysLT}_{1} \mathrm{R}$ is known to be expressed on specific leukocytes, such as monocytes and macrophages [35]. Therefore, we decided to investigate the infiltrating immune cells in wild-type and Cysltr $1^{-/-}$tumors. The AOM/DSS Cysltr ${ }^{-/-}$mice had fewer tumor-infiltrating CD45-positive leukocytes compared to their wild-type counterparts (Figure 4C), which is further supported by the significantly decreased ptprc (CD45) mRNA expression of colons with identified tumors (Figure 5). Moreover, the Cysltr $1^{-/-}$polyps had a significantly decreased tumor infiltration of F4/80-positive macrophages compared to those of the wild-type mice (Figure 4D). Upon further examination of the different immune cell subgroups, the Cysltr $^{-/-}$colons displayed a significant decreased CD4 and $\operatorname{Arg}-1$ mRNA expression, which is indicative of mainly $\mathrm{CD} 4^{+} \mathrm{T}$ cells and type- 2 macrophages, respectively, with a modest decrease in $C D 8$ mRNA levels that was not quite significant (Figure 5).

\section{Inflammatory cytokines in the colon and serum}

The inflammatory response is known to either promote or inhibit tumorigenesis. We, therefore, investigated how the loss of functional CysLT $_{1} R$ affected the proinflammatory cytokines both locally in the colon tissue and systemically in the serum. In Cysltr $1^{-/}$colon and serum samples, a significant decrease was seen in IL-1 $\beta$, TNF $\alpha$ and CXCL1 compared to those from the wild-type mice (Figure 6A and 6B). For the wild-type mice, an increased level of IFN- $\gamma$ was seen in both the colon (mean of $0.77 \mathrm{pg} / \mathrm{ml}$ ) and serum (mean of $0.85 \mathrm{pg} / \mathrm{ml}$ ), while all Cysltr ${ }^{-/}$ IFN- $\gamma$ levels fell below the detection range $(<0.22 \mathrm{pg} / \mathrm{ml})$ (Figure 6A and 6B). This seemingly low IFN- $\gamma$ protein expression in the Cysltr ${ }^{-/-}$mice was further supported by the significant decrease in $I F N-\gamma$ mRNA expression found in the Cysltr $1^{-/-}$colons compared with those of the wild-type mice (Figure 5). No significant difference was detected in colon $I L-10$ mRNA levels (Figure 5) and in colon and serum IL-6 or IL-10 levels for mice, independent of their CysLT R status (Figure 6A and 6B). Interestingly, for the Cysltr $1^{-1-}$ mice, only the colon samples exhibited a decrease in IL-2 (Figure 6A), while only the serum samples exhibited an increase in IL-5 compared to the wild-type colons (Figure 6B). The levels of IL-4 and IL-12 fell below the detection range for both colon and serum samples, and serum IL-2 and colon IL-5 levels also fell below the detection range for all mouse samples.

\section{DISCUSSION}

Studies have shown that the administration of DSS and the induction of inflammation in mice that are 

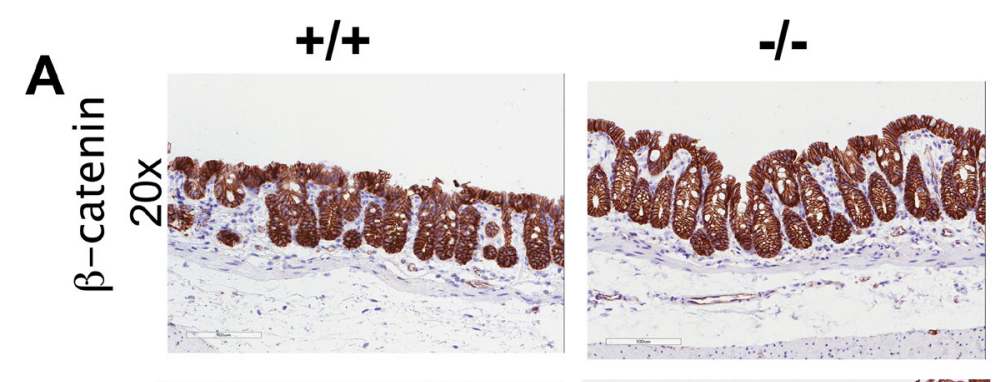

B
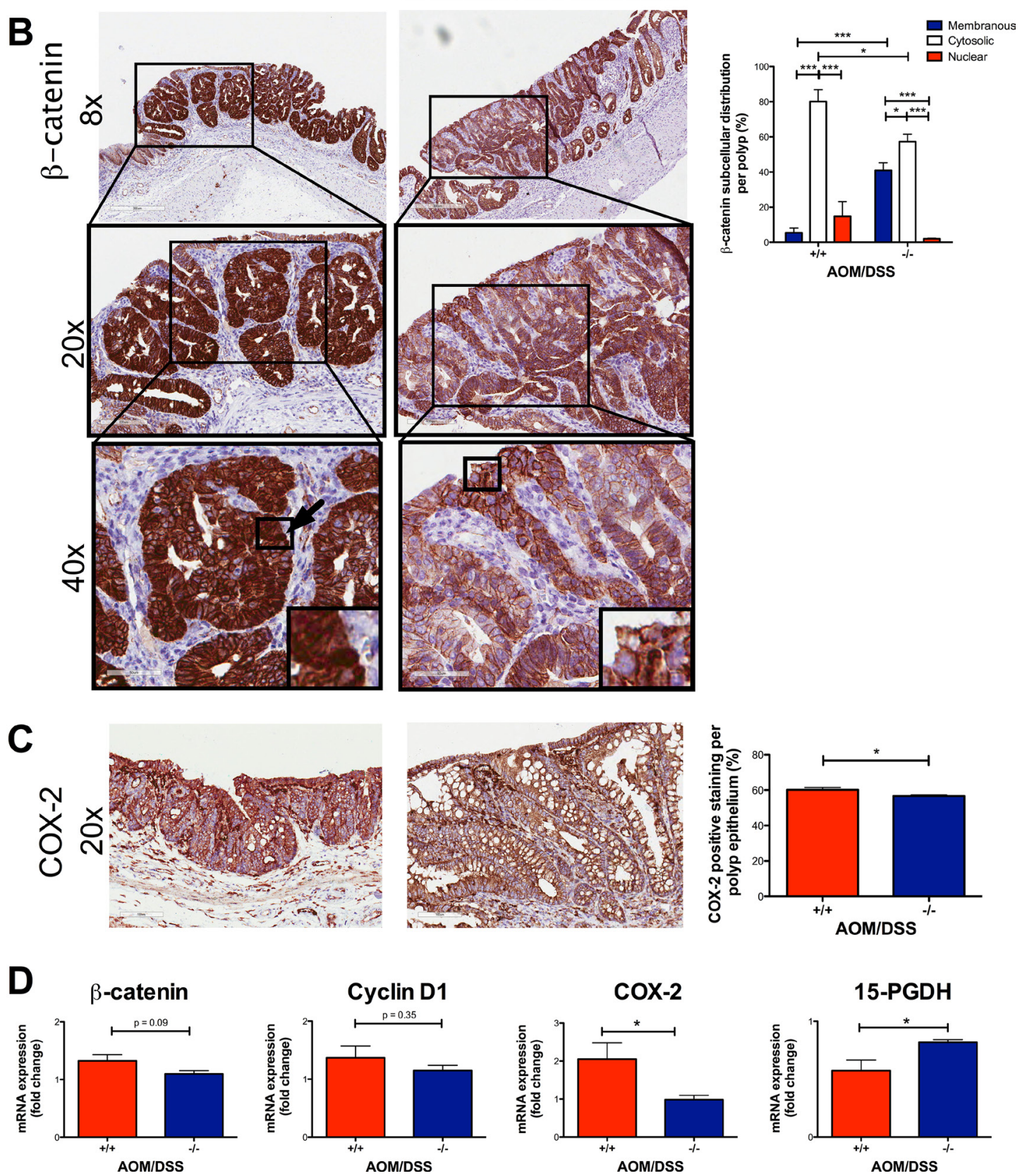

Figure 3: Decreased expression of nuclear $\beta$-catenin and COX-2 in AOM/DSS Cysltr ${ }^{-1-}$ mice. The colons of AOM/DSS female mice with different Cysltrl genotypes ( $n=3-6$ per genotype) were processed for immunostaining. Representative images of (A) non-polyp area stained with $\beta$-catenin (at 20×), (B) polyp area stained with $\beta$-catenin (at $8 \times, 20 \times, 40 \times),(\mathbf{C})$ COX-2 and their corresponding bar diagrams showing the percentages of (B) subcellular localization of epithelial $\beta$-catenin and (C) COX-2 positive epithelial cells within polyps. (D) Relative colon mRNA expression was determined with qPCR for female mice with indicated Cysltrl genotypes $(n=5-7)$ and normalized against Gapdh and untreated wild-type female for $\beta$-catenin, cox-2, 15-PGDH and cyclin D1. Quantitative data are shown as the mean \pm SEM. $* P<0.05,{ }^{*} P<0.01,{ }^{* * *} P<0.001$ by one-way or two-way ANOVA for immunohistochemistry and by $t$-test or MannWhitney test for mRNA data. 
genetically susceptible to intestinal cancer promote the formation of dysplastic lesions in the colon [36, 37]. Therefore, previous findings from our group regarding CysLT $_{1} \mathrm{R}$ signaling indicates that it could increase the susceptibility to colitis-associated colorectal cancer [21]. We have previously demonstrated that the CysLT $\mathrm{R}_{1}$ has a tumor-promoting role in the $\mathrm{Apc}^{\mathrm{Min} /+}$ mouse model of intestinal tumorigenesis [24]. The mechanism of tumor progression in colitis-associated colon cancer (CAC) differs, however, from that of hereditary and sporadic colorectal cancer, exemplified by the early loss of $A P C$ in sporadic pathogenesis, which occurs later in CAC [23].

In the current study, we investigated the effect of the $\mathrm{CysLT}_{1} \mathrm{R}$ by a genetic approach. In an AOM/DSS-

\section{$+/+$}

A
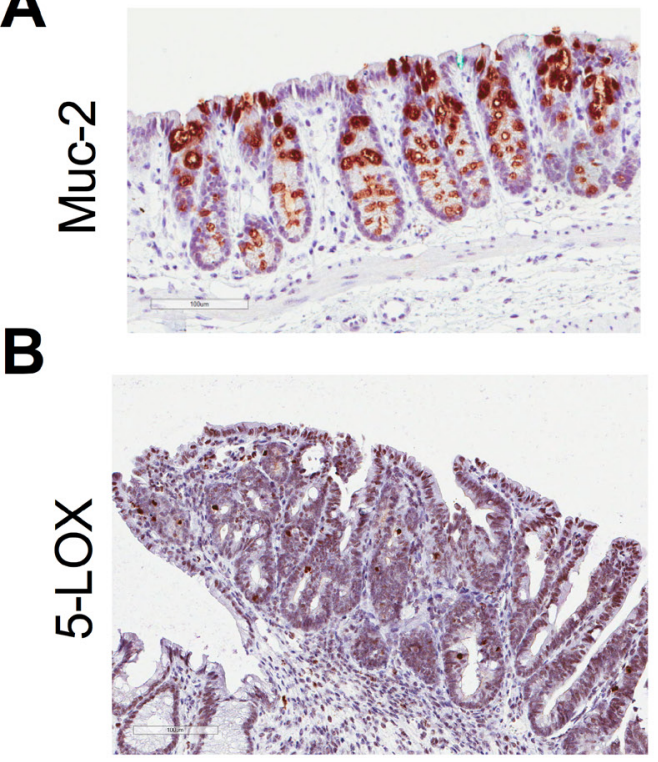

C

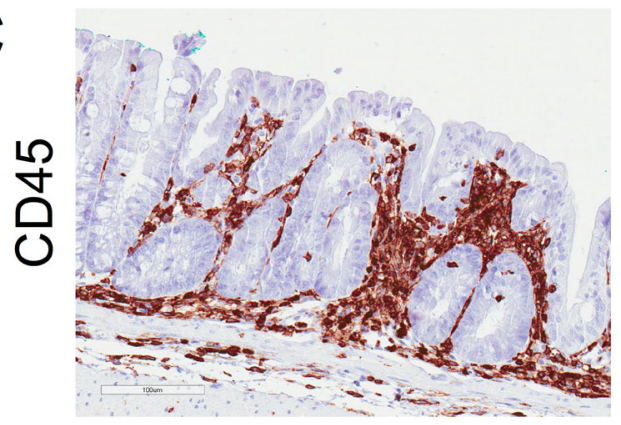

D

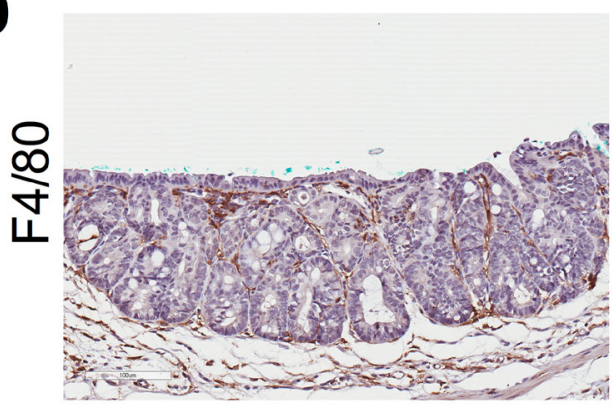

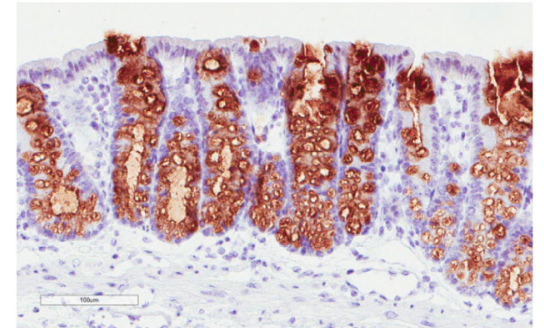

\section{$-1-$}
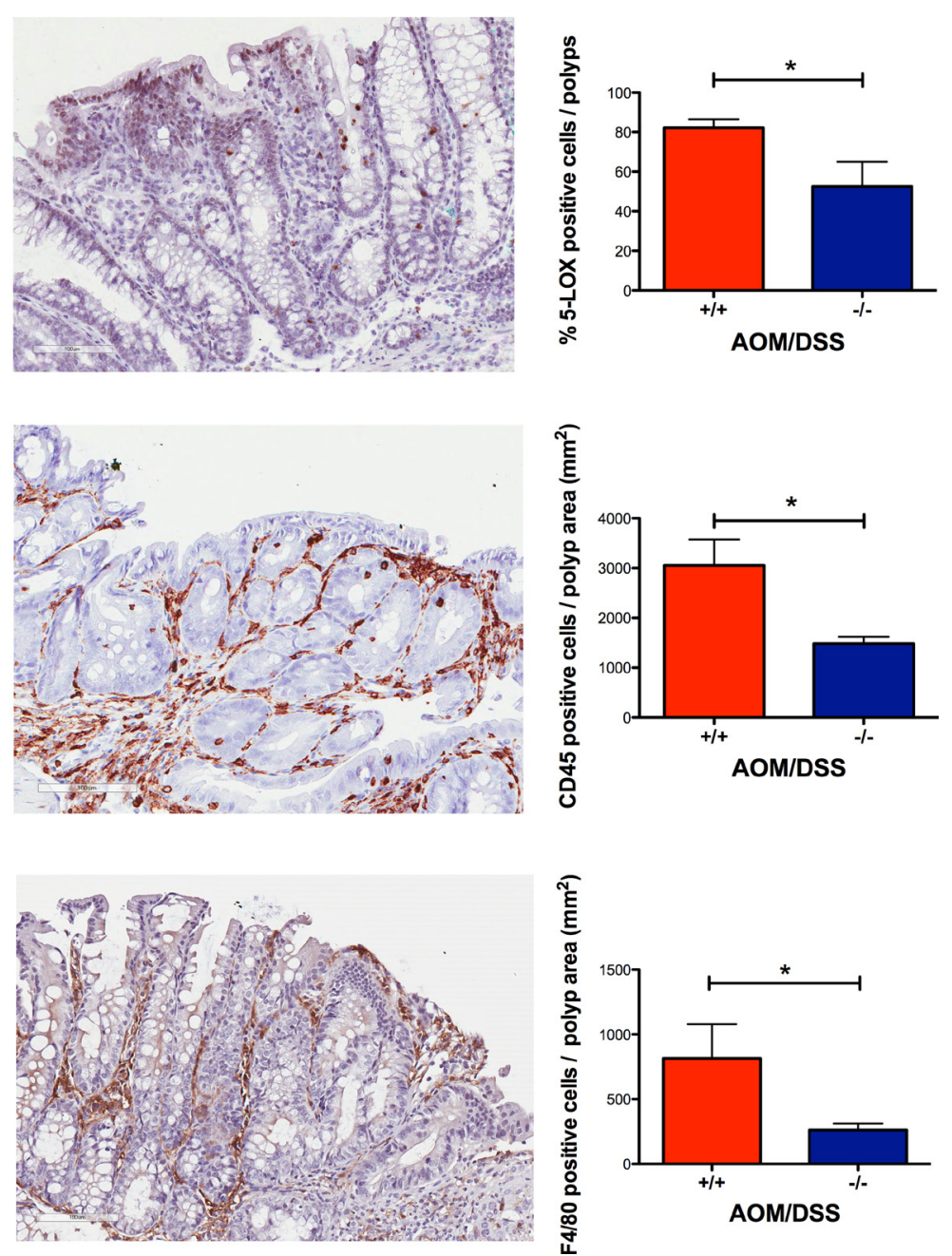

Figure 4: Decreased inflammation in AOM/DSS Cysltr ${ }^{-1-}$ colons with less infiltration of immune cells and increased expression of Mucin 2. Representative images (20×) of colonic crypts stained with (A) mucin 2, and colonic polyps stained with (B) 5-LOX, (C) CD45, and (D) F4/80 with their corresponding bar diagrams showing (A) mucin 2 positive cells per normal crypt, (B) the percentages of 5-LOX positive cells, (C) CD45 positive cells per polyp area $\left(\mathrm{mm}^{2}\right)$ and (D) F4/80 positive cells per polyp area $\left(\mathrm{mm}^{2}\right)$. Quantitative data are shown as the mean \pm SEM, where $n=2-6$ per genotype. ${ }^{*} P<0.05$, ${ }^{* * *} P<0.001$ by $t$-test or Mann-Whitney test. 
induced colitis-associated colon cancer model, we found that female mice with global Cysltrl gene disruption had less severe disease activity compared with wild-type mice. This indicates that Cysltr $1^{-/}$mice have a more favorable outcome, particularly due to their smaller colonic polyps, which are more dysplastic in morphology compared to the adenomas in the wild-type mice.

We have previously demonstrated that the $\mathrm{LTD}_{4}$ mediated $\mathrm{CysLT}_{1} \mathrm{R}$ activation induces proliferation in the intestinal epithelial cells and colon cancer cells. This proliferation can be inhibited in vivo by CysLT $R$ antagonist treatment [21]. Accordingly, the $\mathrm{LTD}_{4}-$ stimulation of $\mathrm{CysLT}_{1} \mathrm{R}$ in colon cancer cells induces $\beta$-catenin nuclear accumulation and transcriptional activity in colon cancer cells with subsequently increased proliferation, migration and invasion with induction of epithelial-mesenchymal transition [19, 38]. We did not observe any difference in $\beta$-catenin localization in non-polyp areas of AOM/DSS wild type and Cysltr $1^{-1-}$ colons. AOM/DSS Cysltr $1^{-/-}$mice exhibited an increased membranous and decreased nuclear $\beta$-catenin expression of the polyp epithelium, with a tendency for decreased total ctnnb1 ( $\beta$-catenin) mRNA levels, and with decreased COX-2 levels. This implies less translocation of $\beta$-catenin to the nucleus, which in turn would suggest a lower activation of the $\beta$-catenin target genes that can promote tumor proliferation and migration.

One important target gene of $\beta$-catenin is $\mathrm{COX}-2$ [29], and the increased expression of COX-2 is necessary for tumors to progress from adenomas to carcinomas [34]. Additionally, in the AOM/DSS mice, increased expression of COX-2 and 5-LOX has been detected in colonic tumors compared with in the surrounding normal mucosa [39]. In patients, increased 5-LOX levels were
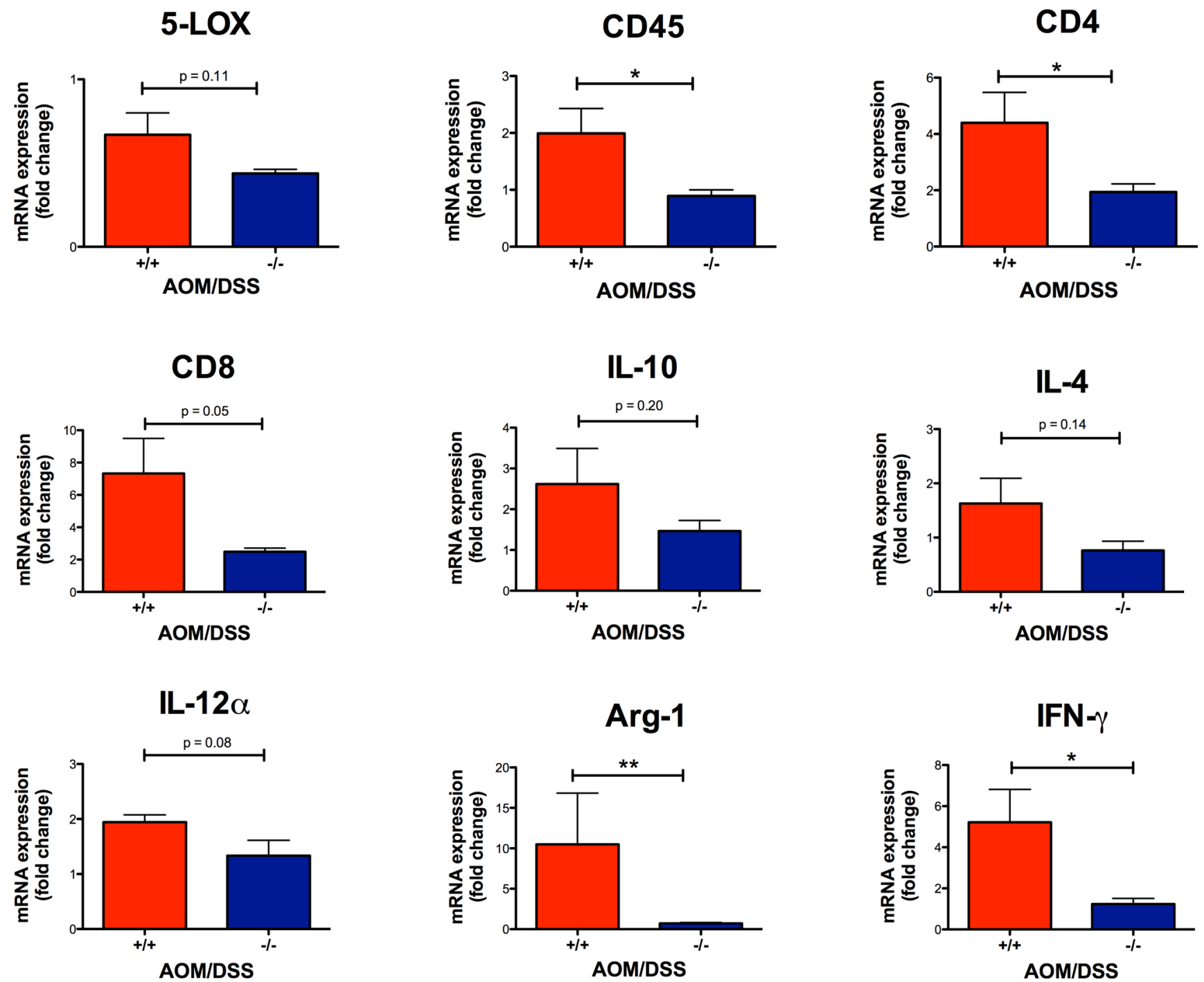

Figure 5: Effect of CysLT ${ }_{1}$ on mRNA levels of AOM/DSS mouse colons. Relative colon mRNA expression was determined with qPCR for AOM/DSS female mice with indicated Cysltr 1 genotypes $(n=5-7)$ and normalized against Gapdh and untreated wild-type female for 5-LOX, CD45, CD4, CD8, IL-10, IL-4, IL-12 $\alpha, A r g-1$ and IFN- $\gamma$. Quantitative data are shown as the mean $\pm \mathrm{SEM}$. $* P<0.05$, $* * P<0.01$ by $t$-test or Mann-Whitney test. 
detected in colon cancer samples compared with in the normal surrounding mucosa, which was correlated with increased CysLT $_{1} \mathrm{R}$ expression [11]. In our AOM/DSS mouse model, the colonic polyps of Cysltr $^{-1-}$ mice displayed decreased protein and mRNA expression of $C O X-2$ and 5-LOX, with increased mRNA levels of the tumor suppressor 15-PGDH [30], which together imply a better outcome, even though no difference was seen

A

Colon

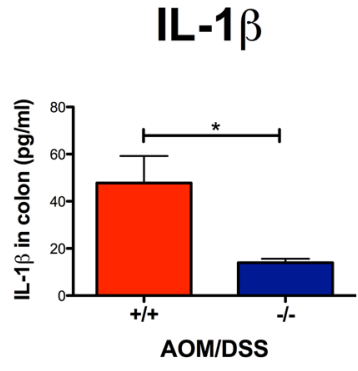

IL-6

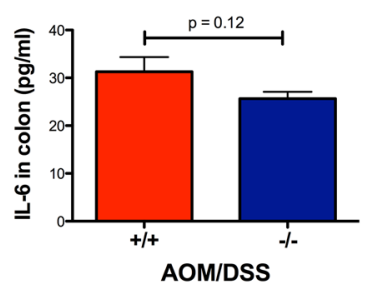

B

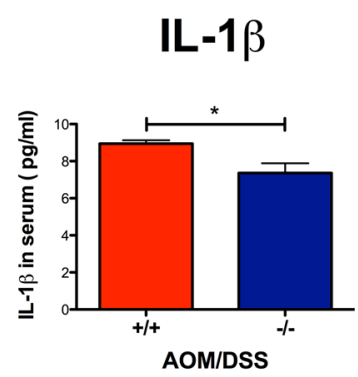

IL-6

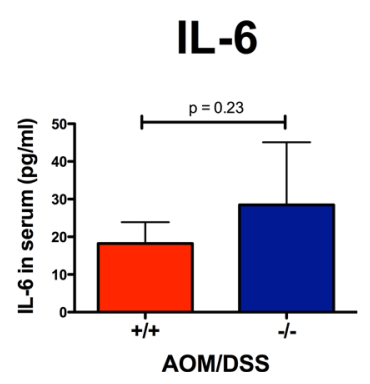

TNF $\alpha$

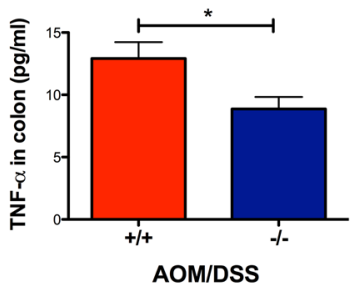

IL-10

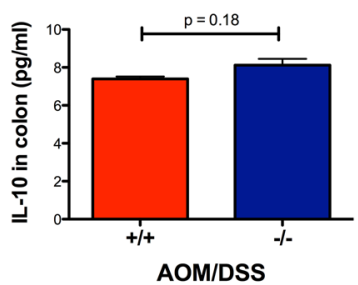

Serum

$\operatorname{TNF}_{\alpha}$

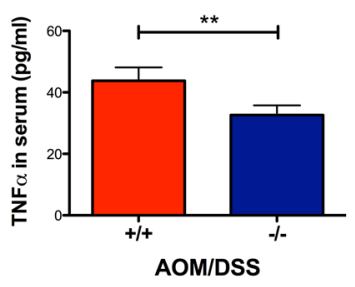

IL-10

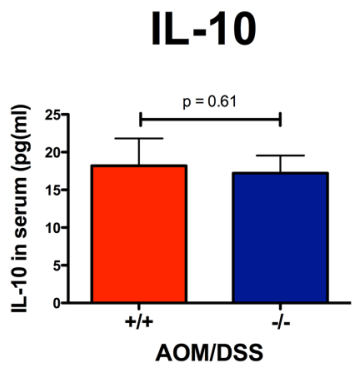

CXCL1

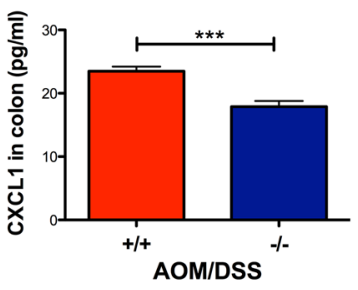

IL-2

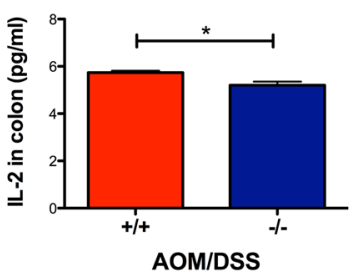

IFN- $\gamma$

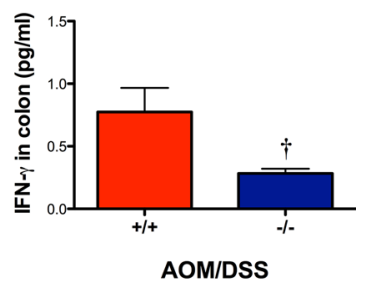

AOM/DSS
CXCL1

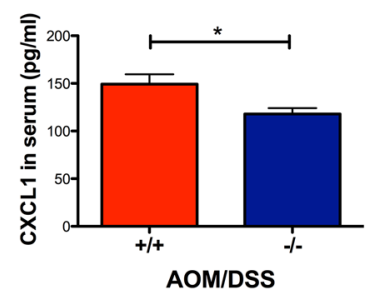

IL-5

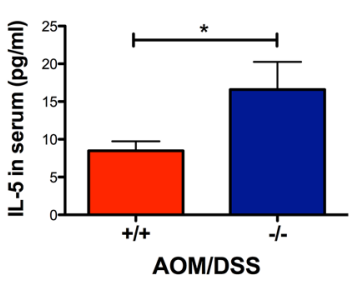

IFN- $\gamma$

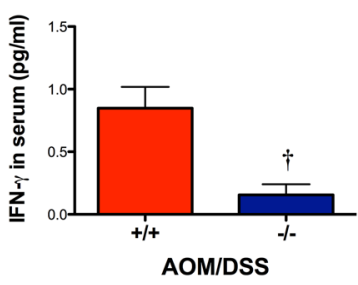

Figure 6: Effect of CysLT $R$ on proinflammatory mediators detected in AOM/DSS colon and serum. Cytokines were quantified from the AOM/DSS serum $(n=3-7)$ and colon samples $(n=2-7)$ using a multiplex sandwich immunoassay format. (A) Inflammatory mediators (IL-1 $\beta$, TNF $\alpha$, CXCL1, IFN- $\gamma$, IL-6, IL-10 and IL-2) quantified from colon lysates. (B) Inflammatory mediators (IL-1 $\beta$, TNF $\alpha$, CXCL1, IFN- $\gamma$, IL-6, IL-10 and IL-5) quantified from serum. Quantitative data are shown as the mean \pm SEM. $* P<0.05$, $* * P<0.01, * * * P<0.001$ by $t$-test or Mann-Whitney test. Values below the detection level were labeled as ( $\dagger$ ). 
in colonic $\mathrm{CysLT}_{2}$ receptor expression between vehicle control and AOM/DSS treated wild type or Cysltr $1^{-/-}$mice (Supplementary Figure 1). Others have shown using Cox-2 knockout mice with DSS-induced colitis that the myeloid and endothelial cell expression of COX-2 has a protective role against colon inflammation [40, 41]. Furthermore, the COX-2 expression and prostanoids derived from the cyclooxygenase pathway were shown to not be essential in colitis-associated cancer in AOM/DSS-treated Cox-2 knockout mice [42]. However, because the $\beta$-catenin activation is important in the early stages of colon tumorigenesis [34], we consider the decrease of COX-2 in Cysltr $1^{-/}$polyps to be more favorable.

The important protective role of Mucin 2 (Muc-2) in colorectal cancer has been demonstrated in Muc2deficient mice, which develop spontaneous intestinal and rectal tumors that eventually progress to carcinomas [43]. In our study, Cysltr $1^{-1-}$ mice displayed significantly increased expression of Muc-2 from normal crypts surrounding the polyps. This is interesting, because the loss of Muc-2 expression contributes to the colorectal cancer progression, and this loss could be facilitated by Wnt/ $\beta$-catenin signaling [44].

In colorectal cancer patients, the frequency and subtype of the tumor-infiltrating lymphocytes have been shown to predict prognosis [45]. Additionally, DSS treatment has been shown to induce acute inflammation in the colon, with increased mucosal permeability, damage and leukocyte infiltration [46]. We, therefore, investigated the tumor infiltration of leukocytes and the expression of different inflammatory mediators in AOM/DSS mice. We observed a decreased polyp infiltration of immune cells (CD45 leukocytes and F4/80 macrophages) in the Cysltr $1^{-1}$ polyps. Since a decrease was also seen in colon mRNA levels of CD4 and Arg-1, it is plausible that the decreased polyp infiltrate also consisted of $\mathrm{CD} 4^{+} \mathrm{T}$ cells and type- 2 macrophages [47]. Previous patient data from our group have shown that tumor associated macrophages (type-2 phenotype) heavily infiltrate tumors and are associated with a poorer prognosis for colon cancer patients [48]. This would suggest a favorable outcome in Cysltr $1^{-/}$mice, with less polyp infiltrated macrophages and less colon Arg-1 levels compared to wild type mice. Additionally, in an $\mathrm{Apc}^{\mathrm{Min}+}$ model of colon cancer, Apc $c^{\mathrm{Min} /+} / \mathrm{Cysltr}^{-/-}$mice tended to have fewer $\mathrm{CD}^{+} \mathrm{CD}^{+}$ $\mathrm{T}$ cells infiltrating polyps [24]. The decrease in CD4 and Arg-1 in Cysltr1 ${ }^{-/-}$mice could be explained by the finding that $\mathrm{CD}^{+}{ }^{+} \mathrm{Th} 2$ cells can facilitate the expression of arginase-1 in murine macrophages, and arginase itself can promote tumor growth and the down-regulation of tumor cytotoxicity [49]. High IL-10 levels have shown to be secreted from colon cancer cells to promote M2 macrophage differentiation [48]. We did, however, not observe any difference in mRNA or protein expression levels of IL-10, between Cysltr $1^{-/}$and wild type mice, and observed higher mRNA and protein expression levels of
IFN- $\gamma$, in wild-type mice. This would indicate a decrease of both type- 1 and type- 2 macrophages in Cysltr $1^{-1}$ mice compared to wild type [50]. Furthermore, IL-5, which can be produced by mast cells and eosinophils, has been shown to promote eosinophil infiltration into tumors and suppress tumor metastasis [51]. We have previously shown that an increased mast cell density has been associated with a better prognosis in colorectal cancer patients, and an increased mast cell number was seen in tumors of AOM/ DSS Cysltr $1^{-/-}$mice [52]. Taken together, the increased mast cell number and increased IL-5 serum levels indicate a more favorable outcome for Cysltr $1^{-1-}$ mice.

At the initial stage of CAC, most cytokines responsible for tumorigenesis are produced by lamina propria macrophages and dendritic cells [34]. We observed an increased expression of the neutrophil chemoattractant CXCL1 in wild type mice, whose expression has been shown to increase in adenomas and adenocarcinomas, indicating a more advanced dysplastic lesions/ACFs, which is supported by our immunohistochemistry data. Wild type mice also exhibited an increase in the proinflammatory cytokines $\mathrm{TNF} \alpha$ and IL- $1 \beta$, which together can further up-regulate the CXCL1 levels [50]. $\mathrm{TNF} \alpha$ is known to have many effects, and it has be involved in the nuclear accumulation of $\beta$-catenin and increased COX-2 expression in AOM/DSS mice [53] which was also evident in the current AOM/DSS wild-type mice. Additionally, IL-1 $\beta$ blockade significantly decreased tumor development in another AOM/DSS mouse model [54], which might explain the less dysplastic lesions found in Cysltr $1^{-1-}$ polyps. Furthermore, in vitro studies with the addition of type- 2 macrophage medium, TNF $\alpha$ or $\mathrm{LTD}_{4}$ to colon cancer cells also induced nuclear accumulation of $\beta$-catenin and increased invasiveness [38]. This might indicate that the type- 2 macrophages secrete $\mathrm{TNF} \alpha$ and $\mathrm{LTD}_{4}$, which can promote more dysplastic polyps partly

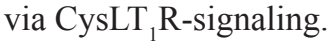

In conclusion, the present genetic approach in a colitis-associated colon cancer model further supports an important role for $\operatorname{CysLT}_{1} \mathrm{R}$ signaling in colon tumorigenesis, driving immune mediators to promote immune cell infiltration in tumors.

\section{MATERIALS AND METHODS}

\section{Animals}

Cysltr1 gene disrupted (Cysltr $\left.{ }^{-/}\right)$mice on a C57BL/6N background were kindly provided by Prof. Frank Austen (Harvard Medical School, Brigham and Women's Hospital, Boston, MA, USA) [53]. A breeding colony was established and maintained at the Lund University Animal Facility, Malmö. All mice were housed in individually ventilated cages, in facilities equipped with 12-h light and dark cycles. All offspring were genotyped for the Cysltrl allele in genomic DNA isolated from 
ear biopsies using polymerase chain reaction (PCR), as previously described [24]. All animal experiments were conducted according to D.Nr. M262-12 and were approved by the Regional Ethical Committee for Animal Research at Lund University, Sweden.

\section{Experimental procedure}

Female 6- to 8-week-old wild type and Cysltr $1^{-/-}$mice were given a single intraperitoneal injection of $10 \mathrm{mg} / \mathrm{kg}$ azoxymethane (AOM) (Sigma-Aldrich Corporation, St. Louis, $\mathrm{MO}, \mathrm{USA}$ ) in $0.9 \% \mathrm{NaCl}$, followed one week later by two 5-day cycles of 2\% dextran sodium sulfate (DSS) (MP Biomedicals, Santa Ana, CA, USA) in drinking water ad libitum, with an intermediate recovery period of two weeks (Figure 1A). The control mice received a vehicle $(0.9 \% \mathrm{NaCl})$ intraperitoneal injection and were not given the DSS treatment. The body weight of the mice was recorded every third day. The mice were euthanized by $\mathrm{CO}_{2}$ asphyxiation either 31 days (early colitis endpoint) or 60 days (late CAC end-point) after the initial AOM/vehicle injection. The complete colon was excised (from anus until cecum) and most of the fat appendages removed without damaging the colon, rinsed with ice-cold phosphate-buffered saline, and opened longitudinally, and the weight and length were recorded. Approximately half of the experimental animals per group (genotype) had their colon fixed flat in $10 \%$ formalin overnight and stored in $70 \%$ ethanol. The size and number of colonic tumors were evaluated using a dissection microscope $(20 \times)$, and the colon was finally subdivided into smaller pieces (approx. $2 \mathrm{~cm}$ ) and finally embedded in paraffin. The rest of the animals had their colon snap-frozen in 1- to 2-cm pieces in liquid nitrogen and stored at $-80^{\circ} \mathrm{C}$ for subsequent RNA extraction and protein quantification.

\section{Immunohistochemistry}

Sectioned $(5 \mu \mathrm{m})$ paraffin-embedded colonic tissues were immunostained using a Dako automatic slide stainer according to the manufacturer's instructions. The sections were stained with rabbit anti-human COX-2 polyclonal antibody (dilution 1:200; Abcam, Cambridge Science Park, Cambridge, UK), rabbit anti-human/mouse 5-LOX polyclonal antibody (dilution 1:100; Cayman Chemical, Ann Arbor, MI, USA) and anti-human/mouse $\beta$-catenin (dilution 1:1000; BD Biosciences, Franklin Lakes, NJ, USA), both anti-human/mouse CD45 polyclonal antibody (dilution 1:100) and anti-human/mouse Mucin 2 polyclonal antibody (dilution 1:400) from Santa Cruz Biotechnology, Santa Cruz, CA, USA), and rat anti-mouse Anti-F4/80 monoclonal antibody (dilution 1:100; Abcam, Cambridge Science Park, Cambridge, UK). All stainings were analyzed on digitally scanned slides (ImageScope v11.2.0.780, Aperio Technologies, Inc., Vista, CA, USA) by two independent investigators blinded to the Cysltr1 status. The expression of 5-LOX within the dysplastic lesions was estimated as the percentage of positivestained cells per polyp. The expression of COX-2 was evaluated by an image-analyzing program HALO v2.0 (Indica Labs; Albuquerque, NM, USA) software to obtain the percentage of COX-2-positive epithelial tissue within the annotated epithelial polyps and is based on pixel algorithms. Epithelial cells were identified with the aid of the Classifier module, and the COX-2 positive staining was detected using the AreaQuantification algorithm, with a manually adjusted positive-staining threshold. The subcellular expression of $\beta$-catenin was assessed within the positive epithelial cells of the polyp. The Muc-2 expression was evaluated as the number of positive cells per crypt, where ten crypts per polyp were assessed. CD45 and F4/80 immunostaining was evaluated as the number of positive cells per polyp area. IgG controls (negative controls) were stained for by using rabbit-HRP, Flex mouse/rabbit-HRP and rabbit anti-rat with subsequent rabbit-HRP staining (all from Dako) (Figure 2C).

\section{Quantitative RT-PCR}

The total RNA was extracted from frozen colon tissue according to the manufacturer's protocol using the RNeasy Plus Mini kit (Qiagen, Hilden, Germany). $1.0 \mu \mathrm{g}$ RNA was used for the cDNA synthesis using RevertAid H Minus M-MuLV Reverse Transcriptase (Thermo Scientific, Waltham, MA). Quantitative PCR was performed using Maxima probe/ROX qPCR master mix and $0.9 \mu \mathrm{M}$ TaqMan probes in a $25-\mu 1$ reaction volume. The TaqMan probes used for ctnnb1 ( $\beta$-catenin), ptgs 2 (COX-2), hpgd (15-PGDH), ccnd1 (cyclin D1), alox5 (5-LOX), ptprc (CD45), CD4, CD8 , IL-12 $\alpha$, arginase-1 (Arg-1), IFN- $\gamma, I L-4$ and IL-10 gene expression were Mm00483039_m1, Mm00478374_m1, Mm00515121_m1, Mm01182747_m1, Mm00432359_m1, Mm01293577_m1, Mm00442754_m1, Mm01182108_m1, Mm00434169_m1, Mm00475988_m1, Mm01168134_m1, Mm00445259_m1 and Mm01288386_m1, respectively (Applied Biosystem, Life Technologies, Waltham, MA). Amplification was performed in a Mx3005P thermocycler (Agilent Technologies, Inc., Santa Clara, CA, USA) using MxPro software (Invitrogen Corp, Carlsbad, CA, USA), and a comparative 2-( $\Delta \Delta \mathrm{Ct})$ method was used to analyze the data. All data were normalized against the housekeeping gene Gapdh (glyceraldehyde-3-phosphate dehydrogenase; Mm99999915_g1) and vehicle control wild type mice.

\section{Cytokine immunoassay}

Blood was collected by cardiac puncture at the time of animal euthanasia, and the non-selective COX inhibitor indomethacin (Sigma-Aldrich, St Louis, MO) was immediately added to the blood samples (at a final 
concentration of $10 \mu \mathrm{g} / \mathrm{ml}$ ), which were allowed to clot for 30 min on ice. Serum was collected after centrifugation in serum separator tubes (Becton Dickinson, Franklin Lakes, NJ, USA) at $6000 \mathrm{~g}$ for $2 \mathrm{~min}$. The frozen colon tissue samples with identified polyps (around $100 \mathrm{mg}$ ) were cut into small pieces and placed in $600 \mu \mathrm{l}$ lysis buffer for homogenization with a sonicator (VirTis VirSonic 50). The sonicated samples were then incubated while mixing at $4^{\circ} \mathrm{C}$ for $20 \mathrm{~min}$ and then centrifuged at 20,000 $\mathrm{g}$ for $15 \mathrm{~min}$ at $4^{\circ} \mathrm{C}$ for supernatant collection.

Ten cytokines were quantified from 4-fold and 2-fold diluted serum or colon samples (run in duplicate or triplicate) using a multiplex sandwich immunoassay format and the electro-chemiluminescence MSD ultrasensitive proinflammatory multiplex kit (Meso-Scale Discovery, Gaithersburg, MD, USA). The MSD multispot array was run according to the manufacturer's protocol. Briefly, 96-well plates pre-coated with capture antibodies for TNF $\alpha$, IL-1 $\beta$, IL-12 (total), IL-2, IL-4, IL-5, IL-6, IL-10 and CXCL1 and INF- $\gamma$ were incubated with serum or colon lysate samples for $2 \mathrm{~h}$. Subsequently, detection antibodies were added, and the plate was incubated for another $2 \mathrm{~h}$. After washing, the plate was read using an MS2400 imager (MSD).

\section{Statistical analysis}

All statistical analyses were performed using GraphPad Prism version 5.0a (GraphPad Software, Inc., San Diego, CA, USA). The unpaired $t$-test (Student's $t$-test) or Mann-Whitney test was used to compare two groups, and the one-way or two-way ANOVA was used to compare more than two groups. A difference was considered significant when the $P$-value was $<0.05$. The data are presented as the mean \pm standard error of the mean (SEM).

\section{Abbreviations}

CAC, colitis-associated colorectal cancer; Cysltr1, Cysteinyl leukotriene receptor 1 ; IL-1 $\beta$, interleukin- $1 \beta$; $\mathrm{TNF} \alpha$, tumor necrosis factor $\alpha$; INF- $\gamma$, interferon $\gamma$; CXCL1, chemokine (C-X-C motif) ligand 1; IL-6, interleukin 6; IL-10, interleukin 10; IL-2, interleukin 2; IL-5, interleukin 5; IL-12 (total), interleukin 12 (total); IL-4, interleukin 4.

\section{Authors'contributions}

Study design: AS, JO, SS. Performing animal experiments: JO, SS, NKC. Sample processing and analysis: JO, SS, NKC, KB, DD. Writing of manuscript: AS, JO, SS.

\section{ACKNOWLEDGMENTS AND FUNDING}

The authors are very appreciative of the excellent technical assistance provided by E. Nilsson, G. Jönsson and M. Juhas. We would also like to thank Prof. Frank Austen (Harvard Medical School, Brigham and Women's Hospital, Boston MA, USA) for providing the Cysltr1 gene disrupted mice. This work was supported by grants from the Swedish Cancer Foundation, the Swedish Medical Research Council, the Foundations at Malmö University Hospital, the Gunnar Nilsson Foundation, the Österlund Foundation to AS. This work was also supported by grants from the Royal Physiographic Society in Lund to $\mathrm{JO}, \mathrm{SS}, \mathrm{NKC}$ and $\mathrm{KB}$.

\section{CONFLICTS OF INTEREST}

The authors declare no conflicts of interest.

\section{REFERENCES}

1. Guagnozzi D, Lucendo AJ. Colorectal cancer surveillance in patients with inflammatory bowel disease: What is new? World J Gastrointest Endosc. 2012; 4:108-16.

2. Andersen NN, Jess T. Has the risk of colorectal cancer in inflammatory bowel disease decreased? World Journal of Gastroenterology. 2013; 19:7561-8.

3. Tang J, Sharif O, Pai C, Silverman AL. Mesalamine protects against colorectal cancer in inflammatory bowel disease. Dig Dis Sci. 2010; 55:1696-703.

4. Clapper ML, Gary MA, Coudry RA, Litwin S, Chang WC, Devarajan K, Lubet RA, Cooper HS. 5-aminosalicylic acid inhibits colitis-associated colorectal dysplasias in the mouse model of azoxymethane/dextran sulfate sodium-induced colitis. Inflamm Bowel Dis. 2008; 14:1341-7.

5. Cathcart MC, Lysaght J, Pidgeon GP. Eicosanoid signalling pathways in the development and progression of colorectal cancer: novel approaches for prevention/intervention. Cancer Metastasis Rev. 2011; 30:363-85.

6. Samuelsson B. The discovery of the leukotrienes. Am J Respir Crit Care Med. 2000; 161:S2-6.

7. Stanke-Labesque F, Pofelski J, Moreau-Gaudry A, Bessard G, Bonaz B. Urinary leukotriene E4 excretion: a biomarker of inflammatory bowel disease activity. Inflamm Bowel Dis. 2008; 14:769-74.

8. Hammerbeck DM, Brown DR. Presence of immunocytes and sulfidopeptide leukotrienes in the inflamed guinea pig distal colon. Inflammation. 1996; 20:413-25.

9. Nishikawa M, Hikasa Y, Hori K, Tanida N, Shimoyama T. Effect of leukotriene C4D4 antagonist on colonic damage induced by intracolonic administration of trinitrobenzene sulfonic acid in rats. J Gastroenterol. 1995; 30:34-40.

10. Brink C, Dahlen SE, Drazen J, Evans JF, Hay DW, Nicosia S, Serhan CN, Shimizu T, Yokomizo T. International Union of Pharmacology XXXVII. Nomenclature for leukotriene and lipoxin receptors. Pharmacol Rev. 2003; 55:195-227.

11. Ohd JF, Nielsen CK, Campbell J, Landberg G, Lofberg H, Sjolander A. Expression of the leukotriene D4 receptor 
CysLT1, COX-2, and other cell survival factors in colorectal adenocarcinomas. Gastroenterology. 2003; 124:57-70.

12. Matsuyama M, Hayama T, Funao K, Kawahito Y, Sano H, Takemoto Y, Nakatani T, Yoshimura R. Overexpression of cysteinyl LT1 receptor in prostate cancer and CysLT1R antagonist inhibits prostate cancer cell growth through apoptosis. Oncol Rep. 2007; 18:99-104.

13. Matsuyama M, Funao K, Hayama T, Tanaka T, Kawahito Y, Sano H, Takemoto Y, Nakatani T, Yoshimura R. Relationship between cysteinyl-leukotriene-1 receptor and human transitional cell carcinoma in bladder. Urology. 2009; 73:916-21.

14. Sveinbjornsson B, Rasmuson A, Baryawno N, Wan M, Pettersen I, Ponthan F, Orrego A, Haeggstrom JZ, Johnsen JI, Kogner P. Expression of enzymes and receptors of the leukotriene pathway in human neuroblastoma promotes tumor survival and provides a target for therapy. FASEB J. 2008; 22:3525-36.

15. Zhang WP, Hu H, Zhang L, Ding W, Yao HT, Chen KD, Sheng WW, Chen Z, Wei EQ. Expression of cysteinyl leukotriene receptor 1 in human traumatic brain injury and brain tumors. Neurosci Lett. 2004; 363:247-51.

16. Magnusson C, Liu J, Ehrnstrom R, Manjer J, Jirstrom K, Andersson T, Sjolander A. Cysteinyl leukotriene receptor expression pattern affects migration of breast cancer cells and survival of breast cancer patients. Int J Cancer. 2011; 129:9-22.

17. Magnusson C, Mezhybovska M, Lorinc E, Fernebro E, Nilbert M, Sjolander A. Low expression of CysLT1R and high expression of CysLT2R mediate good prognosis in colorectal cancer. Eur J Cancer. 2010; 46:826-35.

18. Bellamkonda $\mathrm{K}$, Chandrashekar NK, Osman J, Selvanesan BC, Savari S, Sjölander A. The eicosanoids leukotriene D4 and prostaglandin E2 promote the tumorigenicity of colon cancer-initiating cells in a xenograft mouse model. BMC Cancer. 2016; 16: 425.

19. Salim T, Sand-Dejmek J, Sjolander A. The inflammatory mediator leukotriene D-4 induces subcellular betacatenin translocation and migration of colon cancer cells. Experimental Cell Research. 2014; 321:255-66.

20. Savari S, Vinnakota K, Zhang Y, Sjölander A. Cysteinyl leukotrienes and their receptors: Bridging inflammation and colorectal cancer. World Journal of Gastroenterology. 2014; 20:968-77.

21. Savari S, Liu M, Zhang Y, Sime W, Sjolander A. CysLT1R Antagonists Inhibit Tumor Growth in a Xenograft Model of Colon Cancer. PLoS One. 2013; 8: e73466.

22. Luongo C, Moser AR, Gledhill S, Dove WF. Loss of Apc+ in intestinal adenomas from Min mice. Cancer Res. 1994; 54:5947-52.

23. Mattar MC, Lough D, Pishvaian MJ, Charabaty A. Current Management of Inflammatory Bowel Disease and Colorectal Cancer. Gastrointestinal Cancer Research. 2011; 4:53-61.
24. Savari S, Chandrashekar NK, Osman J, Douglas D, Bellamkond K, Jonsson G, Juhas M, Greicius G, Pettersson S, Sjolander A. Cysteinyl leukotriene 1 receptor influences intestinal polyp incidence in a gender-specific manner in the ApcMin/+ mouse model. Carcinogenesis. 2016; 37:491-9.

25. Yamada Y, Mori H. Multistep carcinogenesis of the colon in Apc(Min/+) mouse. Cancer Science. 2007; 98:6-10.

26. Clapper ML, Cooper HS, Chang WCL. Dextran sulfate sodium-induced colitis-associated neoplasia: a promising model for the development of chemopreventive interventions. Acta Pharmacologica Sinica. 2007; 28:1450-9.

27. Inoue T, Murano M, Kuramoto T, Ishida K, Kawakami K, Abe Y, Morita E, Murano N, Toshina K, Nishikawa T, Maemura K, Shimamoto C, Hirata I, et al. Increased proliferation of middle to distal colonic cells during colorectal carcinogenesis in experimental murine ulcerative colitis. Oncol Rep. 2007; 18:1457-62.

28. Phelps RA, Chidester S, Dehghanizadeh S, Phelps J, Sandoval IT, Rai K, Broadbent T, Sarkar S, Burt RW, Jones DA. A two-step model for colon adenoma initiation and progression caused by APC loss. Cell. 2009; 137:623-34.

29. Araki Y, Okamura S, Hussain SP, Nagashima M, He P, Shiseki M, Miura K, Harris CC. Regulation of cyclooxygenase-2 expression by the Wnt and ras pathways. Cancer Res. 2003; 63:728-34.

30. Mehdawi LM, Prasad CP, Ehrnström R, Andersson T, Sjölander A. Non-canonical WNT5A signaling up-regulates the expression of the tumor suppressor 15-PGDH and induces differentiation of colon cancer cells. Molecular Oncology. 2016; 10:1415-29.

31. Otori K, Sugiyama K, Hasebe T, Fukushima S, Esumi H. Emergence of adenomatous aberrant crypt foci (ACF) from hyperplastic ACF with concomitant increase in cell proliferation. Cancer Res. 1995; 55:4743-6.

32. Siu IM, Pretlow TG, Amini SB, Pretlow TP. Identification of dysplasia in human colonic aberrant crypt foci. Am J Pathol. 1997; 150:1805-13.

33. Pretlow TP, Edelmann W, Kucherlapati R, Pretlow TG, Augenlicht LH. Spontaneous aberrant crypt foci in Apc1638N mice with a mutant Apc allele. Am J Pathol. 2003; 163:1757-63.

34. Terzic J, Grivennikov S, Karin E, Karin M. Inflammation and colon cancer. Gastroenterology. 2010; 138:2101-14.e5.

35. Kanaoka Y, Boyce JA. Cysteinyl Leukotrienes and Their Receptors: Cellular Distribution and Function in Immune and Inflammatory Responses. The Journal of Immunology. 2004; 173:1503-10.

36. Kohonen-Corish MR, Daniel JJ, te Riele H, Buffinton GD, Dahlstrom JE. Susceptibility of Msh2-deficient mice to inflammation-associated colorectal tumors. Cancer Res. 2002; 62:2092-7.

37. Cooper HS, Everley L, Chang WC, Pfeiffer G, Lee B, Murthy S, Clapper ML. The role of mutant Apc in the 
development of dysplasia and cancer in the mouse model of dextran sulfate sodium-induced colitis. Gastroenterology. 2001; 121:1407-16.

38. Vinnakota K, Zhang Y, Selvanesan BC, Topi G, Salim T, Sand-Dejmek J, Jonsson G, Sjolander A. M2-like macrophages induce colon cancer cell invasion via matrix metalloproteinases. J Cell Physiol. 2017 Jan 18. doi: 10.1002/jcp.25808. [Epub ahead of print].

39. Khor TO, Huang MT, Prawan A, Liu Y, Hao X, Yu S, Cheung WK, Chan JY, Reddy BS, Yang CS, Kong AN. Increased susceptibility of Nrf2 knockout mice to colitisassociated colorectal cancer. Cancer Prev Res (Phila). 2008; 1:187-91.

40. Morteau O, Morham SG, Sellon R, Dieleman LA, Langenbach R, Smithies O, Sartor RB. Impaired mucosal defense to acute colonic injury in mice lacking cyclooxygenase-1 or cyclooxygenase-2. J Clin Invest. 2000; 105:469-78.

41. Ishikawa TO, Oshima M, Herschman HR. Cox-2 deletion in myeloid and endothelial cells, but not in epithelial cells, exacerbates murine colitis. Carcinogenesis. 2011; 32:417-26.

42. Ishikawa TO, Herschman HR. Tumor formation in a mouse model of colitis-associated colon cancer does not require COX-1 or COX-2 expression. Carcinogenesis. 2010; 31:729-36.

43. Velcich A, Yang W, Heyer J, Fragale A, Nicholas C, Viani S, Kucherlapati R, Lipkin M, Yang K, Augenlicht L. Colorectal cancer in mice genetically deficient in the mucin Muc2. Science. 2002; 295:1726-9.

44. Pai P, Rachagani S, Dhawan P, Batra SK. Mucins and Wnt/ $\beta$-catenin signaling in gastrointestinal cancers: an unholy nexus. Carcinogenesis. 2016; 37:223-32.

45. Galon J, Costes A, Sanchez-Cabo F, Kirilovsky A, Mlecnik B, Lagorce-Pagès C, Tosolini M, Camus M, Berger A, Wind P, Zinzindohoué F, Bruneval P, Cugnenc PH, et al. Type, Density, and Location of Immune Cells Within Human Colorectal Tumors Predict Clinical Outcome. Science. 2006; 313:1960-4.
46. Kitajima S, Takuma S, Morimoto M. Changes in colonic mucosal permeability in mouse colitis induced with dextran sulfate sodium. Exp Anim. 1999; 48:137-43.

47. Mariani F, Sena P, Roncucci L. Inflammatory pathways in the early steps of colorectal cancer development. World Journal of Gastroenterology. 2014; 20:9716-31.

48. Zhang Y, Sime W, Juhas M, Sjölander A. Crosstalk between colon cancer cells and macrophages via inflammatory mediators and CD47 promotes tumour cell migration. Eur J Cancer. 2013; 49.

49. Munder M. Arginase: an emerging key player in the mammalian immune system. British Journal of Pharmacology. 2009; 158:638-51.

50. Verbeke H, Struyf S, Laureys G, Van Damme J. The expression and role of CXC chemokines in colorectal cancer. Cytokine \& Growth Factor Reviews. 2011; 22:345-58.

51. Ikutani M, Yanagibashi T, Ogasawara M, Tsuneyama K, Yamamoto S, Hattori Y, Kouro T, Itakura A, Nagai Y, Takaki S, Takatsu K. Identification of innate IL-5-producing cells and their role in lung eosinophil regulation and antitumor immunity. J Immunol. 2012; 188:703-13.

52. Mehdawi L, Osman J, Topi G, Sjolander A. High tumor mast cell density is associated with longer survival of colon cancer patients. Acta Oncol. 2016; 55:1434-42.

53. Popivanova BK, Kitamura K, Wu Y, Kondo T, Kagaya T, Kaneko S, Oshima M, Fujii C, Mukaida N. Blocking TNFalpha in mice reduces colorectal carcinogenesis associated with chronic colitis. J Clin Invest. 2008; 118:560-70.

54. Mager LF, Wasmer MH, Rau TT, Krebs P. CytokineInduced Modulation of Colorectal Cancer. Frontiers in Oncology. 2016; 6:96.

55. Kanaoka Y, Maekawa A, Penrose JF, Austen KF, Lam BK. Attenuated zymosan-induced peritoneal vascular permeability and IgE-dependent passive cutaneous anaphylaxis in mice lacking leukotriene $\mathrm{C} 4$ synthase. J Biol Chem. 2001; 276:22608-13. 